\title{
Potassium Phosphate/Sodium Phosphate
}

National Cancer Institute

\section{Source}

National Cancer Institute. Potassium Phosphate/Sodium Phosphate. NCI Thesaurus. Code C29288.

A combination preparation containing potassium phosphate and sodium phosphate used for electrolyte-replacement purposes, dietary supplementation and to acidify urine.

Phosphate, a predominant intracellular anion, plays an important role in energy storage, osteoblastic and osteoclastic activities, regulating serum calcium concentrations and numerous cellular phosphate-transfer reactions. Potassium phosphate and sodium phosphate are used to acidify the urine and lower the urinary calcium concentration. This may reduce rash and odor caused by ammonium in the urine. 